\title{
STK3 wt Allele
}

National Cancer Institute

\section{Source}

National Cancer Institute. STK3 wt Allele. NCI Thesaurus. Code C99478.

Human ST K3 wild-type allele is located in the vicinity of $8 q 22.2$ and is approximately 541

$\mathrm{kb}$ in length. This allele, which encodes serine/threonine-protein kinase 3 protein, is involved in the modulation of both the hippo signaling pathway and protein phosphorylation. 